\title{
Demonyms in the Pacific Alliance countries: morphological and semantic variation
}

\author{
Olga CHESNOKOVA and Marija RADOVIĆ \\ Peoples' Friendship University of Russia (RUDN University) \\ Moscow, Russia
}

\begin{abstract}
The existing research on onomastics does not sufficiently reflect upon the relation between cultural codes and demonyms, having in mind that demonyms universally represent linguistic devices for expressing territorial and regional identity. The article focuses on the complex polyparadigmal analysis of the system of demonyms related to the macrotoponymy of the four founding countries of the Pacific Alliance: Chile, Colombia, Mexico, and Peru. Each of the four founding countries of the Pacific Alliance is characterised by the uniqueness of its culture, historical development, the specifics of the national variant of Spanish that reflects the indigenous influence of substrates and the collective values of the society. The research tasks of the article consist in systemising the morphological devices and the cultural layers of demonyms connected with the administrative division of given countries, detecting the variation parameters, comparing them from the linguacultural point of view. The main material of the research have been 100 official demonyms of Chile, Colombia, Mexico and Peru, and 31 variative denominations. The materials for the research are based on the official websites of the administrative units of the four countries, dictionaries data, diverse types of texts and discourse, as well as the notes of the informants' speech. The research uses such methods as the continuous sampling method based on Internet sources, the analysis of dictionary definitions, the method of semantic interpretation, the morphological analysis, combined with interviews with informants whose interaction is made possible by the complex polyparadigmal analysis of the material. The authors have determined a series of lexemes that function as demonyms, analysed their form and content from the linguistic point of view. It has been revealed that the main tendency in the formation of suppletive demonyms for macrotoponyms are the terrain features and the assessment of ethnic background or mentality. The analysed demonyms manifest the relations of intralingual, intervariant homonymy, as well as hypo-hyperonymic relations. The complex analysis of the material has provided an opportunity to represent the demonym systems of Chile, Colombia, Mexico, Peru as multidimensional and at the same time inherent to the unified functional continuum of entity in Spanish-speaking countries. The research results have led to the conclusion that demonyms act as independent notions and generators of new meanings and allusions. It is recommended to use transliteration when translating suppletive demonyms, while their decoding amplifies the linguacultural competence of Spanish-language students and harmonises the intercultural dialogue with the native speakers of Chilean, Colombian, Mexican and Peruvian national variants of Spanish in the areas of education and business.
\end{abstract}

Keywords: demonym, the Pacific Alliance, linguaculture, variation, association, meaning, interpretation 


\title{
For citation:
}

Chesnokova, Olga S. \& Marija Radović. 2020. Demonyms in the Pacific Alliance countries: Morphological and semantic variation. Russian Journal of Linguistics 24 (4). 1017-1048. DOI: 10.22363/2687-0088-2020-24-4-1017-1048

Научная статья

\section{Катойконимы стран Тихоокеанского Альянса: морфологическое и семантическое варьирование \\ О.С. ЧЕСНОКОВА, М. РАДОВИЧ}

\author{
Российский университет дружбы народов (РУДН) \\ Москва, Россия
}

\begin{abstract}
Аннотация
Существующие ономастические исследования в недостаточной степени охватывают взаимосвязь кодов культуры и катойконимов, тогда как катойконимы универсально формируют языковые средства территориальной и региональной идентичности. Статья посвящена комплексному полипарадигмальному анализу систем катойконимов, связанных с макротопонимией четырех стран-основательниц Тихоокеанского Альянса - Чили, Колумбии, Мексики и Перу. Данные страны характеризуются уникальностью культуры, исторического развития, особенностями национального варианта испанского языка, отражающего субстратное автохтонное влияние и присущие соответствующим социумам ценности. Цель исследования - систематизировать морфологические средства и культурные слои катойконимов, связанных с административным делением данных стран, вывести параметры вариативности, сопоставить их в лингвокультурологическом ключе. Основным материалом исследования послужили 100 официальных катойконимов Чили, Колумбии, Мексики и Перу и 31 вариативное наименование. Источником материала послужили официальные сайты административных единиц четырех стран, данные из словарей, различные виды текста и дискурса, запись речи информантов. В исследовании использованы метод сплошной выборки из интернет-источников, анализ словарных дефиниций, метод семантической интерпретации, морфологический анализ, дополненные опросом информантов. Взаимодействие данных методов обеспечивает комплексный полипарадигмальный анализ материала. В ходе исследования выявлен набор лексем, функционирующих как катойконимы, и проведен лингвистический анализ их формы и содержания. Установлено, что основная тенденция образования супплетивных катойконимов макротопонимов - понятия рельефа, оценка этнического происхождения или ментальности. Исследованные катойконимы обнаруживают отношения внутриязыковой, межвариантной омонимии и гипо-гиперонимические отношения. Комплексный анализ материала позволил представить катойконимные системы Чили, Колумбии, Мексики, Перу как многомерные и одновременно принадлежащие единому функциональному испаноязычному континууму сущности. Полученные результаты позволили заключить, что катойконимы выступают как реалии и генераторы новых смыслов и аллюзий. При переводе супплетивных катойконимов целесообразна транслитерация. Декодирование каокойнимов в целом расширяет лингвокультурологическую компетенцию изучающих испанский язык и гармонизирует межкультурный диалог с носителями чилийского, колумбийского, мексиканского, перуанского национальных вариантов испанского языка в сфере образования и бизнеса.
\end{abstract}

Ключевые слова: катойконим, Тихоокеанский Альянс, лингвокультура, варьирование, ассоцииация, интерпретациия 
Для цитирования:

Чеснокова О.С., Радович М. Катойконимы стран Тихоокеанского Альянса: морфологическое и семантическое варьирование. Russian Journal of Linguistics. 2020. Т. 24. № 4. C. 1017-1048. DOI: 10.22363/2687-0088-2020-24-4-1017-1048

\section{1. Введение: постановка проблемы}

Неизбежное размытие культурных границ в период глобализации обусловливает актуальность осмысления национально-культурной-идентичности в области имен собственных и, в частности, такой интересной и еще мало исследованной категории, как катойконимы (исп. gentilicios, англ. demonym), т.е. названий лиц по месту происхождения и/или проживания. Активность и эмоциональная насыщенность катойконимов варьирует в различных языках и культурах, что связано с типологическими особенностями языка (Радович 2016, Ахметова 2019, Estrada Flórez \& Pérez Adárraga 2020), а также с языковыми вкусами этноса ${ }^{1}$.

В современной лингвистике интерес к ономастике неизменно высокий, о чем свидетельствует, в частности, спектр исследовательских вопросов в журналах «Bonросы ономастики», Acta onomastica, Names и др. Однако существующие ономастические исследования в недостаточной степени охватывают взаимосвязь проприальной лексики и кодов культуры, тогда как на современном этапе развития общества катойконимы, универсально тяготеющие к оценочным коннотациям, служат средством территориальной и региональной идентичности, что подтверждают исследования последних лет на материале различных языков (например, Ильин, Сидорова 2015, Kordic \& Chávez Fajardo 2017, Tent 2018, Chávez Fajardo \& Kordic Riquelme 2019, Estrada Flórez \& Pérez Adárraga 2020).

В нашей статье мы обращаемся к поливариантному и поликультурному испанскому ономастическому материалу, а именно к катойконимам четырех стран-основательниц Тихоокеанского Альянса ${ }^{2}$. Если экономическое значение Тихоокеанского Альянса широко обсуждается (Ripoll 2017), то лингвокультурологические исследования данного торгового блока крайне немногочисленны и находятся лишь в стадии зарождения (Benites \& Lorrain 2017, Чеснокова, Радович, Талавера Ибарра 2020). Предлагаемый в статье полипарадигмальный подход к катойконимам Чили, Колумбии, Мексики и Перу является первым в российской и зарубежной лингвистике опытом комплексной реконструкции и интерпретации катойконимных систем четырех стран-основательниц Тихоокеанского Альянса как форм их лингвокультурологической репрезентации.

${ }^{1}$ Об этом см., в частности, в статье в известном американском журнале, имеющем катойконим в своем названии - The New Yorker, где упомянуты такие предпочитаемые некоторыми жителями номинации, как New Yorkian для нью-йоркца или Mancunian вместо Manchesterian для манчестерца (https://www.newyorker.com/magazine/2013/05/20/new-yorkians).

2 Тихоокеанский Альянс (образован в 2011 г.) - торговый блок, призванный обеспечить свободное передвижение товаров, услуг и капиталов. 
Цель статьи - систематизировать морфологические средства катойконимов Чили, Колумбии, Мексики, Перу, установить культурные слои катойконимов, связанных с административным делением данных стран, вывести параметры вариативности, сопоставить их в лингвокультурологическом ключе. Для достижения данной цели в ходе нашего исследования мы выявили морфологические форманты, культурные слои, ассоциативные связи катойконимов Чили, Колумбии, Мексики, Перу, связанных с макротопонимией соответствующих стран, присущим им административным делением, а также вывели и интерпретировали параметры их национальной специфики и вариативности.

\section{2. Катойконимы как средство выражения идентичности}

Лингвокульутрная идентичность представлена в языке разнообразными средствами (см., например, Bilá, Ivanova 2020; Bilá, Kačmárová, Vaňková 2020; Larina, Ozyumenko, Kurteš 2017; Loester 2017). Одним из таких стредств, на наш взгляд, выступают катойконимы.

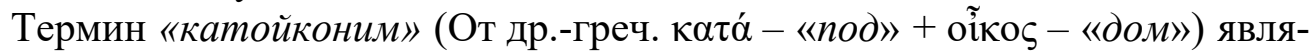
ется синонимом «оттопонимической номинации» и представляет собой частичный русский эквивалент испанского термина gentilicio. В «Кратком понятийно-терминологическом справочнике по этимологии и исторической лексикологии РАН» этноним ${ }^{3}$ толкуется как название этноса - племени, народа, нации, субэтнической группы. Этнонимы подразделяются на aвтоэтнонимы (самоназвания этносов: Deutsch 'немцы', hayer 'армяне') и экзоэтнонимы (названия этносов, данные другими народами: венгры, цъыгане), среди которых выделяются номены с отрицательной коннотацией (москали, хохль), номены для обозначения исчезнувших народов, когда-то населявших определенные территории ${ }^{4}$ Различаются также макроэтнонимы для обозначения крупных этносов и микроэтнонимы, обозначающие небольшие этнические общности, племенные названия. При рассмотрении нормативной кодификации значения испанского термина gentilicio обращает на себя внимание неполное совпадение двух понятий. Согласно словарю Испанской Королевской Академии, gentilicio - это имя прилагательное или существительное, «обозначающее соотнесенность к географии» или «принадлежность или отношение к народам или нациям, а также роду или семье» ${ }^{5}$. Другими испанскими толковыми словарями (Larousse Dictionary 2009) предлагается сходное толкование данной лексемы: «имя прилагательное или существительное, обозначающее происхождение или родину» ${ }^{6}$. Таким

\footnotetext{
${ }^{3}$ от греч. éthnos - племя, народ и ónyma - имя, название.

${ }^{4}$ Словари и энциклопедии на Академике. URL: www.dic.academic.ru (дата обращения: 10 октября 2019).

${ }^{5}$ Diccionario de la Real Academia Española (DRAE). URL: www.dle.rae.es (дата обращения: 10 октября 2019).

${ }^{6}$ gentilicio. (n.d.) Diccionario Enciclopédico Vox 1. (2009). URL: https://es.thefreedictionary. com/gentilicio (дата обращения: 15 июня 2020).
} 
образом, семантическое поле понятия gentilicio оказывается шире, чем у термина «этноним». Согласно испанскому ономасту М. Морера Пересу (Morera 2016) катойконимы могут обладать мотивацией, не связанной с современным топонимом, к которому они относятся. Автор также подчеркивает факты образования топонимов от катойконимов в таких примерах, как España, Italia, Berbería, Rusia, которые представляют дериваты от названий этний: hispano, italo, bereber, ruso (García Padrón \& Morera Pérez 2015: 83).

Типологическая принадлежность испанского языка, структура испанского слова обусловливают активность в нем катойконимов, значительно бо́льшую, нежели, например, в славянских языках. Будучи полинациональным языком, испанский язык имеет общеиспанское ядро и одновременно обнаруживает варьирование на всех уровнях языковой системы, на которое наслаивается варьирование, связанное с менталитетом, национальной языковой нормой и языковой картиной мира каждой испаноязычной нации, присущим им коммуникативным стилем и лингвокультурологическими особенностями, параметры которых (см. Larina 2015, Malyuga, Krouglov \& Tomalin 2018, Mugford 2020) имеют особое преломление в поликультурной испаноязычной среде и в сфере катойконимов. Примечательно, что современные исследования испанского языка выявляют такой его формат, как lingua franca (Pinto \& Santero Pontes 2020).

Чили, Колумбия, Мексика и Перу уникальны по истории и культуре. В каждой из этих стран особое административное деление. Под официиальныли катойконимами мы будем понимать названия жителей, зафиксированные на официальных сайтах соответствующих административных единиц. Например, для колумбийского департамента Антиокия на сайте Википедия ${ }^{7}$ в качестве катойконима указан antioqueño ${ }^{8}$.

Уникальность истории и культуры Чили, Колумбии, Мексики и Перу своеобразно проявляется в сфере их катойконимных номинаций. В данной статье мы пытаемся доказать, что катойконимы выступают в четырех исследуемых странах испанского языка как средства территориальной и региональной идентичности, формируют ономастические доминанты социума как устойчивые модели присвоения и функционирования имени собственного и его производных, а приращения смысла создаются за счет оценочных коннотаций.

\section{3. Материал и методология исследования}

Основным материалом исследования послужили 100 официальных катойконимов Чили, Колумбии, Мексики и Перу, а также 31 вариативное наименование. Как источники материала были использованы официальные

${ }^{7}$ Антиокия, Википедия. URL: https://es.wikipedia.org/wiki/Antioquia (дата обращения: 20 мая 2020)

8 Здесь и далее в тексте испаноязычные катойконимы и отдельные суффиксы для их образования будут приводиться только в форме мужского рода единственного числа. 
сайты административных единиц четырех стран, лексикографические данные, примеры из различных видов текста и дискурса, опрос информантов - носителей чилийского, колумбийского, мексиканского, перуанского национальных вариантов испанского языка в виде свободного ассоциативного эксперимента.

Для исследования был использован полипарадимальный подход к катойконимам четырех испанозычных стран. Его базовым методологическим положением является представление о множественности и равноправии языковых норм в странах испанского языка, сформулированное академиком Г.В. Степановым (Степанов 1976: 159), и понимание вариантности как имманентного свойства языковой системы, восходящее в европейской лингвистике XX в. к работам Пражского лингвистического кружка при разработке принципов функционального описания языка, теории литературного (стандартного) языка, языковой нормализации и кодификации.

Для решения поставленных целей и задач использовались метод сплошной выборки из интернет-источников, анализ словарных дефиниций, семантическая интерпретация, морфологический анализ, дополненные опросом информантов, сочетание которых обеспечило комплексный полипарадигмальный анализ материала. Так же релевантными стали данные психолингвистики, теории дискурса, когнитивной лингвистики, этнолингвистики, истории, социолингвистики, культурологии. Контактологический анализ позволил интерпретировать влияние на катойконимы субстрата автохтонных языков. Взаимодействие данных методов обеспечивает комплексный полипарадигмальный анализ материала.

\section{4. Анализ материала}

\section{1. Катойконимы Чили}

Республика Чили (República de Chile) расположена на юго-западе Южной Америки и простирается в виде узкой полосы земли между Тихим Океаном и Андами. В административном отношении страна разделена на 16 регионов (областей).

Систематизация чилийских катойконимов показывает их наличие для 9 и отсутствие для 7 из 16 номенов чилийских регионов. Название каждого Региона начинается со словосочетания Región de 'Регион': Región de La Araucanía 'Регион-Ла-Араукания'. При этом лексема Región 'Регион' не участвует в деривации однокоренных катойконимов. В случае таких антропотопонимов, как Región del Libertador General Bernardo O'Higgins u Región de Aysén del General Carlos Ibáñez del Campo, причина отсутствия катойконима заключается, на наш взгляд, не только в сложном в звуковом и морфо-синтаксическом отношении для деривации антропонима в качестве топоформанта, но также в наличии в номинации титула исторических личностей, в честь которых Регион получил название: Libertador 'Освободитель', General 'Генерал'. 
Следовательно, образовать емкий по структуре официальный катойконим от данных многокомпонентных топонимов не удается так же успешно, как в случае региона Región de Magallanes y de la Antártica Chilena, жителей которого чилийцы традиционно называют magallánicos. Еще одной и, возможно, главной причиной отсутствия у названий чилийских областей-регионов соответствующего официального катойконима можно признать относительно недавние изменения в политико-административном делении страны (2018 г. $\left.{ }^{9}\right)$, в силу чего данные топонимы и их дериваты еще не стали частью языковой традиции чилийцев и не успели «прижиться» среди населения. В табл. 1 представлены названия регионов Республики Чили и катойконимы в случае их наличия.

таблица 1/ Table 1

Чилийские катойконимы / Chilean demonyms

\begin{tabular}{|c|c|c|}
\hline № & Регион/Область / Region & Катойконим / Demonym \\
\hline 1 & Región de Arica y Parinacota & $\varnothing$ \\
\hline 2 & Región de Tarapacá & tarapaqueño \\
\hline 3 & Región de Antofagasta & antofagastino \\
\hline 4 & Región de Atacama & atacameño \\
\hline 5 & Región de Coquimbo & coquimbano \\
\hline 6 & Región de Valparaíso & $\varnothing$ \\
\hline 7 & Región Metropolitana Santiago & metropolitano \\
\hline 8 & Región del Libertador General Bernardo O'Higgins & $\varnothing$ \\
\hline 9 & Región del Maule & maulino \\
\hline 10 & Región de Ñuble & ñublense \\
\hline 11 & Región del Biobío & $\varnothing$ \\
\hline 12 & Región de La Araucanía & $\varnothing$ \\
\hline 13 & Región de Los Ríos & $\varnothing$ \\
\hline 14 & Región de Los Lagos & laguino \\
\hline 15 & Región de Aysén del General Carlos Ibáñez del Campo & $\varnothing$ \\
\hline 16 & Región de Magallanes y de la Antártica Chilena & magallánico \\
\hline
\end{tabular}

Согласно опросу чилийских информантов (было опрошено 20 человек с высшим образованием), катойконимы для обозначения жителей некоторых провинций/городов из региона функционируют в качестве гиперонимов, т.е. именуют жителей всего региона:

ariqueño (Arica и Región de Arica y Parinacota),

aysenino (Aysén и Región de Aysén del General Carlos Ibáñez del Campo),

porteño (Valparaíso и Región del Valparaíso),

что показывает национально-специфичные чилийские параметры варьирования и иерархии катойконимов.

Вот как об истории региона Región de Aysén del General Carlos Ibáñez del Cатро и использовании катойконима aysenino пишет историк Матео Мартинич Берос:

9 Территориальная организация Чили, Википедия. URL: https://es.wikipedia.org/wiki/ Organizaci\%C3\%B3n_territorial_de_Chile (дата обращения: 17 мая 2020). 
(1) Su aporte, que valorizo especialmente, debe ser ciertamente destacado como el de un aysenino esforzado, honestamente empeñado en hacer luz para el apropiado conocimiento de determinados momentos del pretérito de su tierra (Martinić 2005: 8)

'Его особо ценный вклад, безусловно, должен быть отмечен как вклад трудолюбивого айсенино, с присущим ему достоинством настроенного пролить свет на события прошлого своей родины'.

Отметим также межвариантную омонимию катойконима porteño, относящегося к катойкониму чилийского города Valparaíso и Региона Вальпараисо, к катойкониму столицы Аргентины Buenos Aires, пуэрториканскому топониму Puntarenas, перуанскому Callao, костариканскому Puntarenas, что закреплено лексикографически (Diccionario de americanismos 2010: 1758), и что мы дополняем нашими данными об идентичном катойкониме для колумбийского ойконима Puerto Carreño, венесуэльских Puerto Cabello и Puerto la Cruz. Семантическая реконструкция происхождения данных катойконимов однозначно показывает их связь с лексемой puerto 'порт' и свидетельствует о межвариантной омонимии катойконимов, в которой задействованы чилийские катойконимы от макротопонимов Región de Valparaíso и Valparaíso. Примечательно, что по данным исследования лексикографических источников и опроса информантов, для Мексики, несмотря на обилие прибрежных городов и портов, данный катойконим не обнаружен. Сравним пример из художественного дискурса чилийского писателя Роберто Ампуэро, в котором лексема porteño однозначно относится к жителям Вальпараисо:

(2) A la sede del Club Social y Deportivo Orompello de Valparaíso se llega con dificultad, a menos que seas porteño (Ampuero 2012: 315). 'В спортивный клуб «Оромпельо Вальпараисо» добраться трудно, если ты, конечно, не «портеньо»'.

Продуктивность суффиксов в узуальных в Чили девяти официальных катойконимах выглядит следующим образом:

-ino: 3 (antofagastino, maulino, laguino),

-eño: 2 (tarapaqueño, atacameño),

-ano: 2 (coquimbano, metropolitano),

-ense: 1 (ñublense),

-ico: 1 (magallánico).

Данная картина продуктивности, несмотря на ограниченный количественный признак выборки, почти полностью совпадает с результатами исследований продуктивности суффиксов катойконимов всей Чили (Радович 2016: 57).

Альтернативные варианты катойконимов нами не обнаружены, но следует отметить название жителя Столичной области Región Metropolitana de Santiago $\rightarrow$ metropolitano, отличающееся от названия жителя самой столицы Santiago de Chile $\rightarrow$ santiaguino (вариант - capitalino). 
Общеиспанское значение номена magallánico - относящийся к Магелланову проливу ${ }^{10}$. Национально-специфичное чилийское значение - относящийся к Региону Región de Magallanes y de la Antártica Chilena. Приведем убедительные примеры функционирования номинации magallánico в символизированном названии чилийского регионального информационного интернетпортала и в значении жителя региона Región de Magallanes y de la Antártica Chilena в современном чилийском публицистическом дискурсе:

(3) Dos años se cumplen desde que dos profesionales de las comunicaciones decidieron dar vida a un emprendimiento familiar y posicionar una nueva alternativa al quehacer diario de la comunidad regional: El Magallánico. [...] "Soñamos todos los días, y soñamos en grande. Esperamos que, de concretarse los proyectos, en el futuro podamos cambiar la forma en que los magallánicos se informan y cómo ven hoy las empresas a los medios digitales", comentó (director del medio). ${ }^{11}$

'Прошло два года с того дня, когда два специалиста по коммуникациям решили оживить семейный бизнес и предложили альтернативу повседневной жизни местного общества: «Эль Магальянико». [...] «Мы мечтаем каждый день, и мы мечтаем о большем. Надеемся, что, в случае завершения проектов, в будущем мы сможем изменить представление магелланцев о себе самих и то, как компании видят цифровые медиа сегодня», - сказал директор'

(4) Desde un desayuno típico hasta su propia bandera, asi de potente es la identidad de los magallánicos. Gracias a distintos elementos que los hacen únicos en el país, los habitantes de la zona austral de Chile se caracterizan no tan sólo por vivir en un incomparable entorno natural, sino también por contar con particulares iconos y tradiciones. ${ }^{12}$

'От типичного завтрака до собственного флага - вот насколько неповторима личность магелланц̧а. Уникальность этих жителей южной части Чили не только из-за неповторимой среды их обитания, но и из-за их ритуалов и традиций'.

Примечателен также факт межъязыковой романской омонимии в макротопонимах американского и африканского континентов: чилийский катойконим laguino, производный от топонима общеиспанского происхождения Región de Los Lagos и номинация от омонимичного топонима португальской этимологии для крупного нигерийского города Lagos $\rightarrow$ lagosense. Во время поселения йоруба, первичным номеном для города было название Eko, но высадившийся здесь в 15 веке португальский мореплаватель Руй ди Секейра назвал его Lagos (португальск. 'озера'). В чилийском катойкониме суффикс

${ }^{10}$ Diccionario de la Real Academia Española. URL: www.dle.rae.es (дата обращения: 26 мая 2020).

11 “El Magallánico" cumple dos años. URL: https:/elmagallanico.com/2019/08/ el-magallanico-cumple-dos-anos-informando-a-la-region (дата обращения: 29 мая 2020).

12 Magallanes: curiosidades de un pueblo único. URL: https://www.cocacoladechile.cl/ historias/gente-magallanicos-curiosidades-de-un-pueblo-unico (дата обращения 26 мая 2020). 
добавляется к апокопированному корню Lagos $\rightarrow$ Lag $\rightarrow$ laguino, в то время как в случае испанского варианта нигерийского катойконима суффикс -ense прикреплен к полной форме топонима Lagos $\rightarrow$ lagosense, несмотря на их общероманские корень и мотивационный субстрат.

\section{2. Катойконимы Колумбии}

Республика Колумбия (República de Colombia) - единственная страна Южной Америки, имеющая выход к Тихому и Атлантическому (Карибское море) океанам. В административном отношении страна делится на 32 департамента и Столичный округ, что позволяет рассматривать его наряду с катойконимными номинациями, относящимися к департаментам страны.

Катойконимы Колумбии сведем в табл. 2.

таблица 2 / Table 2

Колумбийские катойконимы / Colombian demonyms

\begin{tabular}{|c|c|c|c|}
\hline № & Департамент / Department & Катойконим / Demonym & Вариант / Variant \\
\hline 1 & Amazonas & amazonense & $\varnothing$ \\
\hline 2 & Antioquia & antioqueño & paisa \\
\hline 3 & Arauca & araucano & $\varnothing$ \\
\hline 4 & Archipiélago de San Andrés y Providencia & sanandresano & raizal \\
\hline 5 & Atlántico & atlanticense & costeño \\
\hline 6 & Bolívar & bolivarense & costeño \\
\hline 7 & Boyacá & boyacense & $\varnothing$ \\
\hline 8 & Caldas & caldense & $\varnothing$ \\
\hline 9 & Caquetá & caqueteño & $\varnothing$ \\
\hline 10 & Casanare & casanareño & Ilanero \\
\hline 11 & Cauca & caucano & $\varnothing$ \\
\hline 12 & Cesar & cesarense & costeño \\
\hline 13 & Chocó & chocoano & $\varnothing$ \\
\hline 14 & Córdoba & cordobés & costeño \\
\hline 15 & Cundinamarca & cundinamarqués & $\varnothing$ \\
\hline 16 & Guainía & guainiano & $\varnothing$ \\
\hline 17 & Guaviare & guaviarense & $\varnothing$ \\
\hline 18 & Huila & huilense & opita \\
\hline 19 & La Guajira & guajiro & costeño \\
\hline 20 & Magdalena & magdalenense & costeño \\
\hline 21 & Meta & metense & Illanero \\
\hline 22 & Nariño & nariñense & $\varnothing$ \\
\hline 23 & Norte de Santander & nortesantandereano & toche \\
\hline 24 & Putumayo & putumayense & $\varnothing$ \\
\hline 25 & Quindío & quindiano & $\varnothing$ \\
\hline 26 & Risaralda & risaraldense & paisa \\
\hline 27 & Santander & santandereano & pingo \\
\hline 28 & Sucre & sucreño & costeño \\
\hline 29 & Tolima & tolimense & $\varnothing$ \\
\hline 30 & Valle del Cauca & vallecaucano & $\varnothing$ \\
\hline 31 & Vaupés & vaupense & $\varnothing$ \\
\hline 32 & Vichada & vichadense & Ilanero \\
\hline 33 & Bogotá & bogotano & cachaco \\
\hline
\end{tabular}


Суффиксы 33 катойконимов, относящихся к названиям департаментов и Столичного Округа, распределены следующим образом:

$$
\begin{aligned}
& \text {-ense: } 16, \\
& \text {-ano: } 10, \\
& \text {-eño: } 4, \\
& \text {-és: } 2, \\
& \text {-o:1, }
\end{aligned}
$$

что вписывается в общие тенденции образования колумбийских катойконимов (Радович 2016: 59). При этом, если, по данным фундаментального труда колумбийских исследователей, самым частотным суффиксом катойоконимов страны в целом оказывается -еп̃o, за которым следуют -ense и -ano (Diccionario de gentilicios de Colombia 2008: 168), то данные по катойконимам от департаментов страны показывают другую картину распределения, поскольку самым частотным оказывается суффикс -ense. Вариантные супплетивные катойконимы от названий департаментов образуют иерархические гипо-гиперонимические отношения. Так, катойконим paisa, по данным опроса информантов, может обозначать жителя департаментов Антиокия и Рисаральда, т.е. выступать их гиперонимом (рис. 1).

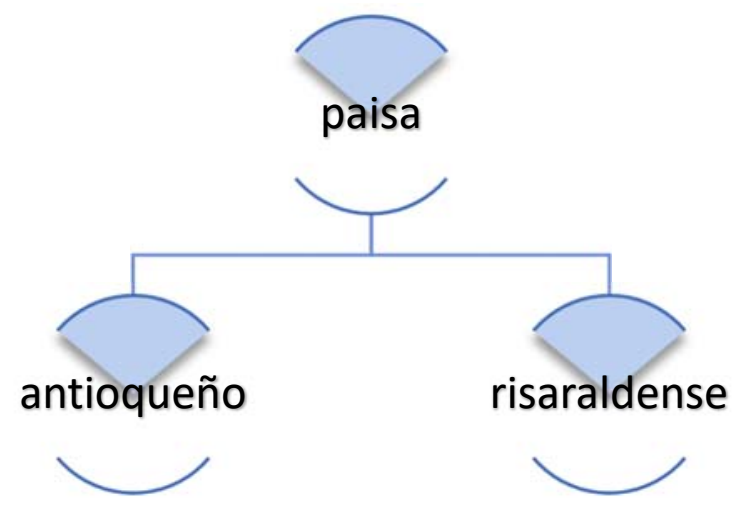

Рис. 1. Значение лексемы paisa / Fig. 1. The meaning of lexeme "paisa"

Реконструируем ассоциативные связи и коннотации альтернативных катойконимов, опираясь на наше предыдущее исследование (Чеснокова 2013). Лексема paisa 'пайса' является апокопой от общеиспанского существительного paisano 'земляк'. Пайса - это жители департамента Антиокия и «Кофейной Ocu». В узком смысле катойконим paisa - это разговорно-обиходный вариант однокоренного с названием департамента Antioquia его официального катойконима antioqueño. В коллективном восприятии колумбийцев naйca ассоциируются с талантом предпринимателей и коммерсантов, находчивостью, словоохотливостью и с богатым воображением (Diccionario de gentilicios de Colombia 2008: 157). Говоря об антиокеньо-пайса, колумбийский лексикограф Р. Монтойя приводит символичную для понимания этнокультурных стереотипов колумбийцев рифмованную поговорку 
(5) Antioqueño, no grande ni pequeño 'Антиокеньо ни велик, ни мал', комментируя ее как оскорбительное речение в адрес меркантильных naŭca (Montoya 2006: 19).

Прагматизм и коммерческую жилку пайса закрепило речение

(6) Antioqueño que se respete, pide rebaja (Luna Cabrera 2005: 135) 'Уважающий себя антиокиец просит скидку'.

Лексема llanero оказывается гиперонимом для номинаций casanareño и metense (рис. 2). Номинация llanero происходит от общеиспанского существительного llano 'равнина'.

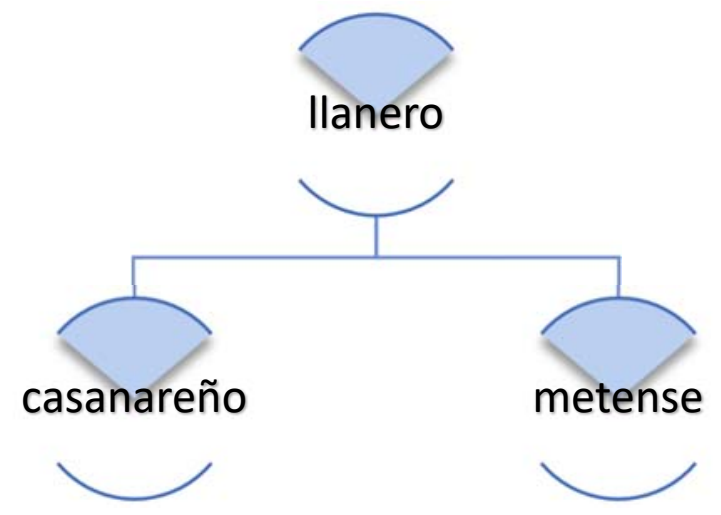

Рис. 2. Значение лексемы Ilanero/ Fig. 2. The meaning of lexeme "Ilanero"

Этнокультурный тип льянеро - это всадник и скотовод; сравним иллюстрацию из колумбийского издания словаря Larousse:

(7) Los llaneros recorrían grandes distancias para trasladar al ganado (Larousse 2009: 378) 'Перегоняя скот, льянеро преодолевали огромные расстояния'.

Этнокультурологический типаж колумбийского, а также венесуэльского llanero имеет параллели с архетипами мексиканского charro 'чарро' и аргентинского gaucho 'гаучо'.

Наиболее многозначным в Колумбии оказывается катойконим costeño, так как он выступает обозначением жителей расположенных на Атлантическом (Карибском) Побережье Колумбии департаментов Атлантико, Боливар, Сесар, Кордова, Ла-Гуахира, Магдалена, Сукре, т.е. лексема costeño - гипероним катойконимов atlanticense, bolivarense, cesarense, cordobés, guajiro, sucreño (рис. 3).

Уникальность географического положения Колумбии состоит в том, что она единственная страна Латинской Америки, имеющая выход к Тихому и Атлантическому океанам. В языковом сознании колумбийцев противопоставлены жители Карибского побережья и жители остальной части страны, что нашло отражение в следующей стереотипной шутке: 
(8) Aunque Colombia tiene dos costas, se entiende por Costa la del Mar Caribe por ser la más rumbera. La otra Costa es más pacífica (запись информантов).

'Хотя Колумбия имеет два выхода к морю, под побережьем понимается Карибское побережье, поскольку оно более «заводное». Другое побережье более «тихое»'.

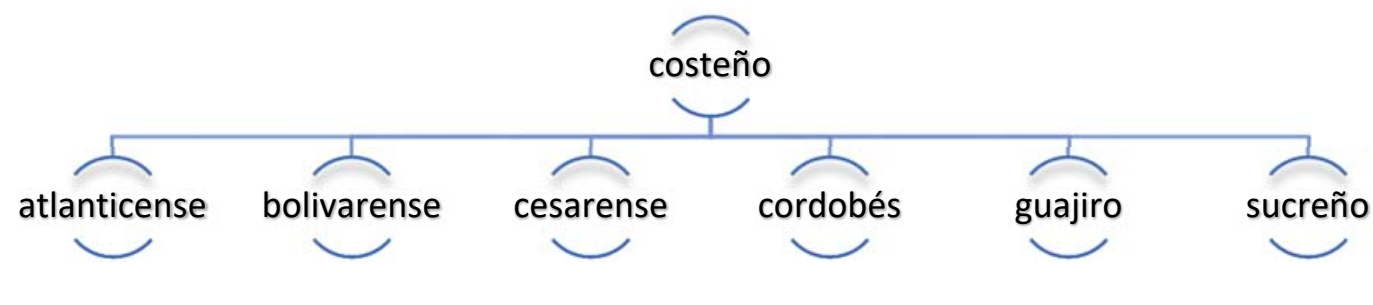

Рис. 3. Значение лексемы costeño/ Fig. 3. The meaning of lexeme "costeño"

Знаменитый музыкальный жанр костеньос - vallenato 'вальенато' (Vargas López 2018), признанным мастером которого был Рафаэль Эскалона (1927-2009), а в настоящее время популярнейший колумбийский исполнитель Карлос Вивес, функционирует как альтернативное название жителей города Вальдедупар: valduparensel vallenato (Estrada Flórez \& Pérez Adárraga 2020).

Рассмотрим важнейшие вариантные супплетивные катойконимы.

Cachacos. Обиходное сознание колумбийцев разделяет население страны на жителей высокогорных районов cachacos 'качакос' и costeños 'костеньос', проживающих на побережье (Bernal, Munévar \& Barajas 2014). В узком смысле лексема cachaco именует жителей Боготы, является разговорно-обиходным синонимом катойконима bogotano, а также реализует дополнительные смыслы хорошо одетого и любезного человека (Bogotálogo 2016: 60). Как синоним лексемы cachaco для обозначения жителей Боготы функционирует имя rolo, возникшее как звукоподражательное обозначение креолов, имевших особую манеру произнесения согласного /rr/ (Diccionario de gentilicios de Colombia 2008: 157). Аксиологически как автоэтноним боготинцев лексема rolo в настоящее время не приветствуется (Bogotálogo 2016, p. 261). В широком смысле лексема cachaco называет не только жителей столицы страны, но и жителей всей природно-географической зоны Altiplano Cundiboyacense 'Альтиплано Кундибойясенсе', исконной территории коренного населения Колумбии чибча-муисков, оказываясь экзонимом, так как номинация осуществлена с точки зрения «костеньос» (Breve Diccionario de colombianismos 2009: 39). Фразеологизм

(9) Más contento que cachaco en playa (Luna Cabrera 2005: 137) 'Более довольный, чем качако на пляже' 
апеллирует к высокомерному восприятию «качакос» со стороны «костеньос», которые живут на карибском побережье Колумбии и имеют доступ к прекрасным пляжам, от которых «качакос» отрезаны географически. Пренебрежительное обозначение костеньос со стороны качакос - corroncho или corruncho, имеющее в речи колумбийцев также значения 'грубый', 'заурядный' (Breve Diccionario de colombianismos 2009: 81). «Словарь американизмов» дает значения лексемы cachaco с территориальными пометами Колумбии, Венесуэлы и Эквадора. Колумбийские значения - 'житель внутренних районов страны', ‘уроженец Боготы'; переносные колумбийские и венесуэльские значения - 'элегантный' и 'хорошо одетый', эквадорское значение - 'экстраверт, нелюдим' (Diccionario de americanismos 2010: 328), что свидетельствуют о диффузности значений и межвариантной омонимии этой номинации.

Как свойственно обиходному сознанию, представления об изысканности в одежде могут аксиологически трансформироваться в отрицательную и даже презрительную характеристику. Именно помета desp. 'пренебрежительное' сопровождает колумбийское значение лексемы cachaco «для жителей прибрежных районов - житель столицы или внутренних районов страны» в Словаре Рено Ришара (Richard 2000: 94). Суффиксальный дериват от лексемы cachaco $\rightarrow$ cachacueco означает в Панаме гомосексуалиста (Diccionario de americanismos 2010: 328); таким образом идея хорошо одетого человека сгенерировала новые смыслы и аллюзии деривата катойконима cachaco.

Из случаев семантической деривации примечателен вариантный катойконим департамента Huila (официальный катойконим - huilense) opita 'опита', что мотивировано разговорным приветствием ора, ассоциирующимся в коллективном сознании колумбийцев с особенностями речи жителей департамента Уила (Diccionario de gentilicios de Colombia 2008: 155).

По данным нашего свободного ассоциативного эксперимента (участвовало 15 информантов с высшим образованием), альтернативные колумбийские катойконимы, как и катойконимы в строгом смысле слова, синтагматически сочетаются с типичными для катойконимов именами (García Padrón \& Morera Pérez 2015: 85), т.е. с названиями лиц, животных, растений, минералов, природных явлений:

(10) Shakira es costeña, en particular, barranquillera, con ancestros árabes 'Шакира - костенья с арабскими корнями';

(11) Juanes es paisa por su origen 'Хуанес - naйса по происхождению';

(12) comida raizal /opita 'райсальская еда' 'еда из Уила';

(13) petróleo llanero 'нефть из зоны Льянос'.

\section{3. Катойконимы Мексики}

Мексика (Мексиканские Соединенные Штаты, Estados Unidos Mexicanos) - крупнейшая испаноязычная страна, и фактически кажды четвертый испаноговорящий в мире - это мексиканец. В административном 
отношении Мексика разделена на 32 федеративные единицы (entidad federativa): 31 штат и столицу страны - город Мехико (Ciudad de México), который до 2016 года имел статус Федерального округа (Distrito Federal). Каждое официальное название штата начинается со словосочетания Estado Libre y Soberano de 'Свободный и Суверенный штат', например, Estado Libre y Soberano de Aguascalientes 'Свободный и Суверенный штат Агуаскальентес', Estado Libre y Soberano de México 'Свободный и Суверенный штат Мехико'.

Все названия штатов имеют официальные однокоренные катойконимы. Табл. 3 систематизирует катойконимы названий штатов.

таблица 3 / Table 3

Мексиканские катойконимы / Mexican demonyms

\begin{tabular}{|c|c|c|}
\hline № & Штат & Катойконим \\
\hline 1 & Aguascalientes & aguascalentense \\
\hline 2 & Baja California & bajacaliforniano \\
\hline 3 & Baja California Sur & sudcaliforniano \\
\hline 4 & Campeche & campechano \\
\hline 5 & Coahuila de Zaragoza & coahuilense \\
\hline 6 & Colima & colimense \\
\hline 7 & Chiapas & chiapaneco \\
\hline 8 & Chihuahua & chihuahuense \\
\hline 9 & Durango & duranguense \\
\hline 10 & Estado de México & mexiquense \\
\hline 11 & Guanajuato & guanajuatense \\
\hline 12 & Guerrero & guerrense \\
\hline 13 & Hidalgo & hidalguense \\
\hline 14 & Jalisco & jalisciense \\
\hline 15 & Michoacán de Ocampo & michoacano \\
\hline 16 & Morelos & morelense \\
\hline 17 & Nayarit & nayarita \\
\hline 18 & Nuevo León & neoleonés \\
\hline 19 & Oaxaca & oaxaqueño \\
\hline 20 & Puebla & poblano \\
\hline 21 & Querétaro de Arteaga & queretano \\
\hline 22 & Quintana Roo & quintanarroense \\
\hline 23 & San Luis Potosí & potosino \\
\hline 24 & Sinaloa & sinaloense \\
\hline 25 & Sonora & sonorense \\
\hline 26 & Tabasco & tabasqueño \\
\hline 27 & Tamaulipas & tamaulipeco \\
\hline 28 & Tlaxcala & tlaxcalteca \\
\hline 29 & Veracruz & veracruzano \\
\hline 30 & Yucatán & yucateco \\
\hline 31 & Zacatecas & Zacatecano \\
\hline
\end{tabular}


По частотности форманты катойконимов штатов распределены следующим образом:

-ense: 13,
-ano: 8,
-eño: 3,
-eco: 3,
-ino: 2,
-eca: 1,
-és: 1.

По данным исследования Н.Ю. Журавлевой, первые три места в образовании катойконимов Мексики в целом занимают форманты -ense, -eño, -есо (Журавлева 2013). Официальные катойконимы от названий штатов выявляют 7 формантов. При лидирующем положении суффикса -ense, второе и третье места занимают суффиксы - апо и -еп̃o, а суффикс -есо оказывается на четвертом месте. Форманты -есо и -еса образуют фонемные варианты, восходят к суффиксу -е́catl значения 'родом из' (Cabrera 2003: 157) в языке ацтеков nahuatl 'науатль', представляя одно из сравнительно немногих (Дитрих 2002: 70, Moreno de Alba 2001: 111, 118) не вызывающих сомнений свидетельств влияния языка науатль на грамматику испанского языка Мексики. Катойконимы от названий штатов дают другую картину: при лидирующем положении суффикса -ense, второе и третье места занимают суффиксы -ano и -eño, а суффикс -есо оказывается на четвертом месте.

Если название штата состоит из нескольких компонентов, то катойконим может образовываться как от одного из них (Querétaro de Arteaga $\rightarrow$ queretano; San Luis Potosí $\rightarrow$ potosino), так и от обоих одновременно, что относится к топонимам как из сложного слова (Aguascalientes $\rightarrow$ aguascalentense), так и словосочетания (Baja California $\rightarrow$ bajacaliforniano). Примечательно, что, как и в случае с катойконимами от крупнейших административных единиц Чили, номен статуса административный единицы (Región 'Регион' ('Область') для Чили; Estado 'Штат' для Мексики) в образовании катойконимов не участвуют. Многокомпонентные названия штатов образуют катойконим по принципу универбации от индейского компонента: Michoacán de Ocampo $\rightarrow$ michoacano, Coahuila de Zaragoza $\rightarrow$ coahuilense, что подтверждает значимость индейского компонента в кодах мексиканской лингвокультуры (Чеснокова 2020). Все случаи комбинации форманта -есо/-еса регистрируются для автохтонных топонимов-индихенизмов. Топонимы Chiapas, Tamaulipas, Tlaxcala восходят к языку науатль, топоним же Yucatán - к языку майя, отразив, по распространенной версии интерпретации, первые контакты испанцев с местным населением (Поспелов 2007: 93). Примечательно, что в случае однозначно майякского по происхождению топонима Yucatán 'Юкатан', катойконим так же образован посредством форманта из языка науатль: Yucatán $\rightarrow$ yucateco, что можно расценить как устойчивость кодов автохтонного мексиканского лингвокультурного субстрата. 
Рассмотрим явление варьирования в катойконимах от названий штатов. Сайты штатов и информанты не дают большого количества вариантов официальных катойконимов. Остановимся на самых ярких примерах. Официальным катойконимом штата Aguascalientes является номинация от обоих корней: agua 'вода' caliente 'горячий' $\rightarrow$ aguascalentense, а вариативным - искусственно созданная игровая номинация hidrocálido, образованная сложением греческого корня hidro 'вода', широко представленного в терминологии естественных наук (ср. hidrógeno 'водород’) и восходящего к латинскому calídus прилагательного cálido 'теплый', 'горячий'. Катойконим hidrocálido употребляется в различных видах текста и дискурса и сочетается со всеми выделяемыми для катойконимов (García Padrón \& Morera Pérez 2015: 85) именами. Приведем иллюстрации словосочетаний из «Словаря Испанского языка Мексики»: la capital hidrocálida, un torero hidrocálido ${ }^{13}$, 'столица Штата Агуаскальентес', 'тореро из Агуаскальентес'. По данным опроса информантов, многие жители штата Агуаскальентес отрицательно относятся к катойокониму hidrocálido, считая его не аутентичным, хотя в языковом сознании мексиканцев он не обладает отрицательными коннотациями. Менее частотными в силу сложности звуковой формы, но структурно допустимыми вариантами для обозначения жителей штата Агуаскальентес являются лексемы hidrotermopolitano, aquicalidense. Поскольку столица штата Агуаскальентес имеет то же название, что и штат, идентичная вариативность наблюдается и в отношении названий жителей столицы.

Релевантный национально-специфичный параметр варьирования мексиканских катойконимов заключается в том, что в макротопонимии Мексики в десяти случаях из тридцати одного название штата (Aguascalientes, Campeche, Colima, Chihuahua, Durango, Guanajuato, Oaxaca, Puebla, San Luís Potosí, Zacatecas) и название столицы (Aguascalientes, Campeche, Colima, Chihuahua, Durango, Guanajuato, Oaxaca, Puebla, San Luís Potosí, Zacatecas) совпадают, и так же совпадают их официальные катойконимы. Данный факт обусловливает как омонимию, так одновременно и иерархические отношения катойконимов. В качестве модельной рассмотрим иерархию катойконимов штата Aguascalientes. Из 11 муниципий, на которые разделен штат Aguascalientes, официальные катойконимы в википедии ${ }^{14}$ указаны для пяти муниципий:

Aguascalientes $\rightarrow$ aguascalentense

Calvillo $\rightarrow$ calvilense,

Pabellón de Arteaga $\rightarrow$ pabellonense,

Tepezalá $\rightarrow$ tepezalense,

El Llano $\rightarrow$ llanense.

${ }^{13}$ Diccionario del Español de México (DEM). URL: http://dem.colmex.mx, El Colegio de México, A.C. (дата обращения: 28 мая 2020).

14 Агуаскальентес, Википедия. URL: https://es.wikipedia.org/wiki/Aguascalientes (дата обращения: 1 июня 2020). 
Примечательно, что катойконим от муниципии El Llano $\rightarrow$ llanense в штате Агуаскальентес, будучи мотивированным общеиспанским обозначением равнины llano, отличается суффиксальным формантом от катойконима колумбийской зоны llanos, которым является llanero, несмотря на идентичность общеиспанского происхождения мексиканского ойконима и названия зоны равнин - важной черты рельефа Колумбии.

Катойконимы от названия штата Aguascalientes и названия столицы Aguascalientes образуют омонимы и одновременно находятся в гипо-гиперонимических отношениях (рис. 4).

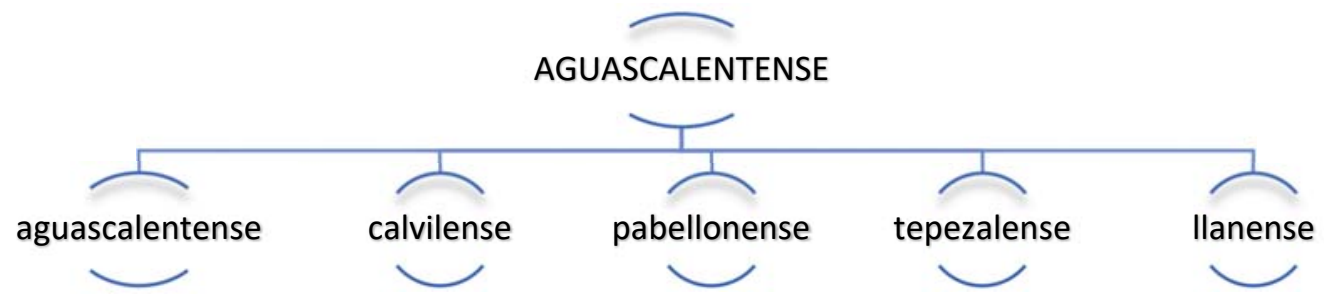

Рис. 4. Иерархия катойконимов штата Агуаскальентес /

Fig. 4. The hierarchy of demonyms of the state Aguascalientes

Данное явление омонимии и одновременно гипо-гиперонимии характерно для катойконимов штатов Aguascalientes, Campeche, Colima, Chihuahua, Durango, Guanajuato, Oaxaca, Puebla, San Luís Potosí, Zacatecas, в которых совпадают названия штата и название его столицы и что представляет, в свою очередь, релевантную черту мексиканской катойконимной системы.

Общеизвестный в Мексике и в паниспанском пространстве вариант катойконима veracruzano - это jarocho. Классик мексиканской лексикографии Франсиско Сантамария в «Словаре мексиканизмов» указывает на историческую обусловленность номинации jarocho обозначением крестьян, прекрасных наездников, сравнимых с чарро (charro) центральной части страны, побережья Веракрус и особенно района Sotavento, которая стала использоваться для номинации жителей порта Веракрус, а переносно - обозначать крепкого и здорового человека (Santamaría 2000: 630). «Словарь испанского языка Мексики» дает определение лексеме jarocho как 'уроженец Веракруса (города и порта)', 'относящийся к этим территориям', приводя примеры puerto jarocho 'Веракрусский порт', carnaval jarocho 'Веракрусский карнавал', а также 'социально-маргинальный жаргон' ${ }^{15}$. Примечательно, что общеиспанское значение прилагательного jarocho - 'грубый', 'неотесанный' ${ }^{16}$. В Латинской Америке лексема jarocho оказывается межвариантным омонимом: мексиканским

${ }^{15}$ Diccionario del Español de México (DEM). URL: http://dem.colmex.mx, El Colegio de México, A.C. (дата обращения: 28 мая 2020)/

${ }^{16}$ Diccionario de la Real Academia Española. URL: https://dle.rae.es/jarocho (дата обращения: 28 мая 2020)/ 
обозначением жителей штата Веракрус и порта Веракрус (лексема porteño не используется), 'веселый', 'живой' в Колумбии, 'сильный (о ненависти)' в Гондурасе: odio jarocho (Diccionario de americanismos 2010: 1212).

Интересную картину вариативности дает катойконим штата Chihuahua: chihuahuense, образованный с помощью самого частотного для катойконимов Мексики форманта -ense. Дериват от названия штата Chihuahua с формантом -еп̃o: chihuahueño относится исключительно к обозначению породы собак (русск. 'чихуахуа').

Структурно возможный вариант катойконима от макротопонима Jalisco $\rightarrow$ jalisquillo имеет презрительные и оскорбительные коннотации, кодифицированные в нормативном «Словаре испанского языка Мексики», сравним текстовый пример:

(14) “¡Esos jalisquillos llorones, que no saben perder!”"17 ‘Эти нытики из Халиско не умеют проигрывать!'.

Мексиканские катойконимы образуют собственную подвижную систему, но одновременно предстают как часть непрерывного континуума катойконимов испанского языка. Целый пласт мексиканских топонимов является кальками испанских топонимов. Возможная омонимия катойонимов снимается за счет варьирования суффиксального форманта, сравним: Puebla (Мексика) $\rightarrow$ poblano; Puebla (Huelva, España) $\rightarrow$ puebleño; Puebla (Huesca, España) $\rightarrow$ puéblense, Puebla (Ciudad Real) $\rightarrow$ poblato, Puebla (Comunidad de Madrid) $\rightarrow$ pueblero; Durango (México) $\rightarrow$ durangueño, Durango (España) $\rightarrow$ durangués.

В случае с названием штата San Luis Potosí и его одноименной столицы мотивация отразила сравнение богатства обнаруженных в XVI в. месторождений с городом Потоси (Potosi) в Боливии, центром горнодобывающей промышленности. Мексиканский катойконим от трехкомпонентного названия San Luis Potosí образован от компонента Potosí $\rightarrow$ potosino и оказывается омонимичным обозначением жителей департамента Потоси и его одноименной столицы в Боливии.

Отдельных комментариев заслуживает катойконим yиcateco (сниженноразговорный апокопиванный вариант уиса) с индейским формантом -есо. Эта многозначная лексема реализует полный спектр функций катойконимов, а также обозначает вариант языка майя штатов Кампече, Юкатан и КинтанаРоо и реалию huipil 'уипиль' - хлопковую с вышивкой рубашку индеанок ${ }^{18}$. В коллективном языковом сознании мексиканцев юкатеки ассоциируются с особой манерой произношения и простодушием. Отсюда следующие фразеологизированные стереотипы:

${ }^{17}$ Diccionario del Español de México (DEM). URL: http://dem.colmex.mx, El Colegio de México, A.C. (дата обращения: 1 июня 2020)/

18 Diccionario del Español de México (DEM). https://dem.colmex.mx/Ver/yucateco, El Colegio de México, A.C. URL: https://dem.colmex.mx/Ver/yucateco (дата обращения: 31 мая 2020). 
(15) Yucateco al yucateco se le ve y se le oye 'Юкатек узнает юкатека по речи и внешнему виду’ (сравним русск. «Рыбак рыбака видит издалека»). Вариантом мексиканской пословицы

(16) El que nace tepalcate no a comal tiznado llega (Velasco Valdés 1998: 66) 'Кто родился осколком, никогда не станет («долбаным») глиняным горшком' (русский аналог «Где родился, там и пригодился») стало сохраняющее с исходным вариантом рифму речение

(17) El que nace yucateco, ni a comal tiznado llega 'Кто родился юкатеком, никогда не станет («долбаным») глиняным горшком’.

Уникальные параметры вариативности образуют катойконимы от названия страны, названия штата Мехико (Estado Libre y Soberano de México) и названия столицы страны - города Мехико (Ciudad de México, в разговорнообиходном стиле - La Ciudad de México). C 2016 г. город Мехико получил статус тридцать второго федерального государственного образования (entidad federativa), наравне со штатами (estado). Индейское происхождение топонима México не вызывает сомнений у лексикографов и этимологов. Однако версии мотивирующих признаков весьма различны, и их количество, по оценкам Л. Кабреры, превышает двадцать гипотез (Cabrera 2002: 92). Многозначность топонима México снимается в катойконимах. Катойконим для жителей страны - mexicano 'мексиканец', жителей штата Мехико - mexiquense, тогда как жители крупнейшей городской агломерации Латинской Америки города Мехико (Ciudad de México) называются capitalino, chilango. До 2016 г., когда город Мехико (Ciudad de México) имел статус Федерального Округа (Distrito Federal), его жителей называли defeño, от аббревиатуры Distrito Federal $\rightarrow D F \rightarrow$ defeño.

Общеиспанское значение лексемы capitalino, $n a$ - относящийся или связанный со столицей государства ${ }^{19}$. В Латинской Америке лексема capitalino, помимо номинации жителей мексиканской столицы, регулярно воспроизводится как вариант однокоренного катойконима для столицы Гондураса Tegucigalpa $\rightarrow$ tegucigalpense / capitalino / comayagüelense и для столицы Чили Santiago de Chile $\rightarrow$ santiaguino / capitalino, что отражено на соответствующих официальных сайтах.

Важные лингвокультурологические коннотации содержит лексема chilango. «Словарь американизмов» кодифицирует лексему chilango как мексиканизм, «относящийся к Федеральному Округу» и сопровождает ее пометами рор «разговорное» и cult «литературное», указывая на связь с лексемой shilango (Diccionario de americanismos 2010: 522), которая так же кодифицируется как «относящийся к Федеральному Округу» (Diccionario de americanismos 2010: 1951). Франсиско Сантамария определяет лексему chilango как вариант shilango, используемый в Bеракрусе (Santamaría 2000: 384). В свою очередь, происхождение лексемы shilango (вариант xilango)

${ }^{19}$ Diccionario de la Real Academia Española. URL: https://dle.rae.es/capitalino+ (дата обращения: 2 июня 2020). 
определено знаменитым мексиканским лексикографом из майякского xilaan 'взлохмаченные волосы или волосы с перхотью' и кодифицировано как разговорное прозвище, которое в Веракрусе дают жителям центральной части страны (Santamaría 2000: 971). Таким образом, мотивационная реконструкция лексемы chilango показывает ее связь с региональным словоупотреблением и стереотипом. Устойчивость и сохранность этой лексемы сопровождались расширением спектра ее пользователей. Современный онлайн Словарь испанского языка Мексики дает лексему chilango с пометой Coloq «разговорное» и толкованием значения через синоним capitalino $^{20}$. В настоящее время варианты shilango/xilango не используются, тогда как лексема chilango употребляется повсеместно как разговорно-непринужденное обозначение жителей мексиканской столицы, перейдя из разряда экзонимов в разряд автоэтнонимов; сравним пример из записи речи (в свободном ассоциативном эксперименте участвовало 20 человек с высшим образованием) мексиканского дипломата-уроженца мексиканской столицы:

(18) A los que somos de la Ciudad de México siempre nos han llamado chilangos (antes defeños también). 'Нас, уроженцев Мехико, всегда называли чиланго (раньше также дефеньос)'. Пример о сотруднице из города Мехико:

(19) Miroslava Cruz Aldrete es chilanga de nacimiento (1971) y de corazón ${ }^{21}$ 'Мирослава Крус Альдрете (1971) чиланга по рождению и по характеру'. В сниженно-разговорном узусе лексема chilango реализует неодобрительные коннотации экзонима; ср. текстовый пример из словаря мексиканского жаргона:

(20) Un chilango buena onda es como santa claus, ninguno de los dos existen. $^{22}$ 'Симпатичный чиланго как Санта Клаус: их просто нет'.

\section{4. Катойконимы Перу}

Республика Перу (República del Perú) - третья по площади, после Бразилии и Аргентины, страна Южной Америки. В административном отношении страна разделена на 24 департамента и 2 провинции с особенным статусом, не принадлежащие никакому департаменту (Provincia Constitucional de Callao, Provincia de Lima).

Аналогично топонимической картине в Мексике, в перуанской системе макротопонимов также наблюдаются многочисленные индихенизмы (Áncash, Apurímac, Ayacucho, Cuzco, Lambayeque, etc.), однако, в соответствии с местным субстратом - кечуанского происхождения и происхождения из языка аймара, в первую очередь, которые составляют подавляющее большинство перуанских названий департаментов, если сравнить их с примером топонима

${ }^{20}$ Diccionario del Español de México (DEM). URL: http://dem.colmex.mx. El Colegio de México, А.С. (дата обращения: 30 мая 2020).

${ }^{21}$ Equipo. URL: https://infoling.org/?lang=es\&p=equipo (дата обращения: 28 мая 2020).

22 Jergozo. URL: https://jergozo.com/significado/chilango (дата обращения: 28 мая 2020). 
общеиспанского происхождения La Libertad и с названиями христианской тематики Madre de Dios, San Martín. В табл. 4 представлены катойконимы департаментов и провинций Республики Перу.

Продуктивность суффиксов катойконимов (табл. 5) в основном совпадает с общей картиной частотности суффиксов катойконимов Перу. Также следует отметить, что альтернативных катойконимов нами не обнаружено (было опрошено 14 информантов с высшим образованием).

таблица 4 / Table 4

Перуанские катойконимы / Peruvian demonyms

\begin{tabular}{|c|c|c|}
\hline № & Департамент / Department & Катойконим / Demonym \\
\hline 1 & Amazonas & amazonense \\
\hline 2 & Áncash & ancashino \\
\hline 3 & Apurímac & apurimeño \\
\hline 4 & Arequipa & arequipeño \\
\hline 5 & Ayacucho & ayacuchano \\
\hline 6 & Cajamarca & cajamarquino \\
\hline 7 & Cuzco & cuzqueño \\
\hline 8 & Huancavelica & huancavelicano \\
\hline 9 & Huánuco & huanuqueño \\
\hline 10 & Ica & iqueño \\
\hline 11 & Junín & juninense \\
\hline 12 & La Libertad & liberteño \\
\hline 13 & Lambayeque & lambayecano \\
\hline 14 & Lima & limeño \\
\hline 15 & Loreto & loretano \\
\hline 16 & Madre de Dios & madrediosense \\
\hline 17 & Moquegua & moqueguano \\
\hline 18 & Pasco & pasqueño \\
\hline 19 & Piura & piurano \\
\hline 20 & Puno & puneño \\
\hline 21 & San Martín & sanmartinense \\
\hline 22 & Tacna & tacneño \\
\hline 23 & Tumbes & tumbesino \\
\hline 24 & Ucayali & ucayalino \\
\hline 25 & provincia constitucional de Callao & chalaco \\
\hline 26 & provincia de Lima & limeño \\
\hline
\end{tabular}

таблица 5 / Table 5

Продуктивность суффиксов перуанских катойконимов /

The suffix productivity of Peruvian demonyms

\begin{tabular}{|l|l|}
\hline \multicolumn{1}{|c|}{ СУФФИКС } & \multicolumn{1}{c|}{ ПРИМЕРЫ } \\
\hline -eño (11) & $\begin{array}{l}\text { apurimeño, arequipeño, cuzqueño, huanuqueño, iqueño, liberteño, limeño, } \\
\text { pasqueño, puneño, tacneño, limeño }\end{array}$ \\
\hline -ano (6) & ayacuchano, huancavelicano, lambayecano, loretano, moqueguano, piurano \\
\hline -ino (4) & ancashino, cajamarquino, tumbesino, ucayalino \\
\hline -ense (4) & amazonense, juninense, madrediosense, sanmartinense \\
\hline
\end{tabular}

В катойконимах от макротопонимов Перу мы вновь выявляем пример межвариантной омонимии: для катойконима перуанского региона La Libertad характерно использование номинации liberteño, в то время как жителя 
одноименного департамента в Эль-Сальвадоре называют libertadense . $^{23}$. Топоформант в виде определенного артикля, как и в случае чилийского региона Лос-Лагос, не входит в структуру катойконима.

О значении супплетивного катойконима chalaco существует множество теорий, согласно которым его однозначное происхождение из языка кечуа реконструируется как «дома из прочных сушеных листьев тростника и кукурузы, построенные на песчаной местности» (chhalla-ako), «индеец, собирающий листья тростников» (chhallakuni) или «проживающий в порту/рыбак» (challahaque) ${ }^{24}$.

В романе «Город и псы» Марио Варгас Льоса описывает серранос, жителей андского региона с выраженными индейскими признаками, следующим образом:

(21) "Y cuando el Ricardo se curó me dijo: "cuídate siempre de los serranos, que son lo más traicionero que hay en el mundo. Nunca se te paran de frente, siempre hacen las cosas a la mala, por detrás. Esperaron que yo estuviera bien borracho, con pisco que ellos mismos me convidaron, para echárseme encima. [...]",25 'После выздоровления Рикардо сказал мне: «Всегда будь осторожен с серранос, они те еще предатели. Никогда ни перед чем не остановятся, всегда все со зла делают, с задними мыслями. Они ждали, когда я напьюсь писко, которым сами меня угощали, чтобы наброситься на меня ${ }^{26}$.

Такое явление, как подчеркивание социальной разницы между слоями перуанского населения, до сих пор препятствует созданию коллективного ощущения инклюзивности и гордости культурным разнообразием, которое свойственно Перу. Приведем пример из медийного дискурса, в котором объясняется функционирование лексем serrano и cholo.

(22) “Serrano" (como se denomina a los andinos) y "cholo" (el mestizo de sangre europea e indigena) son utilizadas como palabras despectivas. En las discotecas de moda de Lima es dificil ver personas de piel oscura ofacciones indigenas. Los pocos que se atreven a intentar entrar son rechazados en la puerta $^{27}$." “Серрано (как называют жителей андского региона) и чоло (метис европейского и индейского происхождения) используются как оскорбительные слова. В модных дискотеках Лимы сложно увидеть темнокожих людей с индейскими чертами. Тех немногих, кто осмеливается попробовать пройти туда, сразу выгоняют на входе'.

${ }^{23}$ Diccionario de la Real Academia Española. URL: https://dle.rae.es/libertadense?m=form (дата обращения: 2 июня 2020). 2020)

${ }^{24}$ Chimpum Callao. http://www.chimpum-callao.com/historia.html (дата обращения: 25 мая

${ }^{25}$ Vargas Llosa, Mario. La ciudad y los perros. Edición conmemorativa de la Real Academia Española y la Asociación de Academias de la Lengua Española. 2012. 768 p.

${ }^{26}$ Перевод наш. - M.P.

${ }^{27}$ El Diario, Peru, un país racista contra sí mismo: „,Es una forma de „, blanquearse ““.. URL: https://www.eldiario.es/desalambre/Peru-pais-racista-mismo_0_254775486.html (дата обращения: 2 июня 2020) 
Примечательно, что общеиспанская номинация serrano обладает разным функционированием в зависимости от страны и, несмотря на ее пейоративное значение в Перу, в Мексике, Колумбии, Чили, Эквадоре и Боливии, имеет лишь географическую коннотацию. Тем не менее, ее перуанское функционирование не зафиксировано в Словаре Испанской Королевской Академии, в котором упоминается его отношение к горному рельефу, а также к уругвайскому департаменту Lavalleja ${ }^{28}$. Словарь Испанской Королевской Академии кодифицирует широкое употребление в ряде латиноамериканских стран номинации cholo, которую следует отнести к разряду реалий, в значении человека индейского происхождения, а также индейца, перенявшего привычки белого «западного» человека ${ }^{29}$.

В интервью газеты BCC Mundo перуанский журналист Марко Авилес дает определение понятия cholos и производных от него лексических единиц, таких как choledad (созвучного с soledad 'одиночество' и выражающего противоречивое чувство гордости и грусти) или сложное существительное pitucholo (pituco 'представитель высшего слоя общества' + cholo 'разбогатевший чоло'). Авилес также приводит примеры словосочетания cholo power c англицизмом power ‘власть' в значении 'успешный чоло', 'чоло с модельной внешностью’ и пейоративно окрашенный глагол cholear, означающий оскорбление чоло по рассовому признаку ${ }^{30}$, что свидетельствует о значимости лексемы cholo ‘чоло’ в коллективном сознании перуанцев и ее высоком деривационном и семантическом потенциале.

\section{5. Обсуждение результатов}

Обобщая формальные и семантические параметры систем катойконимов названий крупнейших административных единиц Чили, Колумбии, Мексики, Перу, мы выявляем наличие в них единых общеиспанских формантов, которые, тем не мнеее, обнаруживают уникальное распределение по странам и выраженные тенденции к локализации. Примечательны для динамики испаноязычной катойконимной лексики случаи различий общеиспанских и национально-специфичных значений, как, напрмер общеиспанское значение номена magallánico - относящийся к Магелланову проливу, а национальноспецифичное чилийское значение - относящийся к региону Región de Magallanes y de la Antártica Chilena. Общеиспанская номинация serrano обладает разным функционированием в зависимости от страны и, несмотря на ее пейоративное значение в Перу, в Мексике, Колумбии, Чили, Эквадоре и Боливии, имеет лишь географическую коннотацию. Симптоматичен и факт отсуствия для Мексики, несмотря на обилие прибрежных городов и портов, катойконима porteño, свойственного Чили, Колумбии, Перу и другим южно-

${ }^{28}$ Diccionario de la Real Academia Española. URL: https://dle.rae.es/serrano?m=form (дата обращения: 2 июня 2020).

${ }^{29}$ Ibid.

${ }^{30}$ BBC News, Por qué a muchos peruanos les cuesta reconocerse como cholos. URL: https://www.bbc.com/mundo/noticias-america-latina-37489332 (дата обращения: 2 июня 2020). 
американским странам. Языковые вкусы и преференции носителей четырех исследованных национальных вариантов испанского языка, таким образом, различны, в области катойконимов.

Также наблюдается дифференцирующая функция суффиксов в морфологии катойконимов в случае межвариантной и межъязыковой омонимии макротопонимов. В мексиканской системе катойконимов фиксируется индейский (из языка науатль) формант -есо, что свидетельствует об устойчивости влияния индейского субстрата на морфологию мексиканского национального варианта испанского языка. Для катойконимов Чили примечательно их значительное отсутствие в связи с относительно недавним (2018) изменением административного деления страны и многокомпонентностью официальных названий регионов, трудно поддающихся для деривации катойконимов. Универбация, которая представляет диахронический процесс слияния устойчивого выражения, состоящего из нескольких слов в одно, представлена в основном в мексиканских и чилийских катойкониках. Системы катойконимов четырех стран обнаруживают своеобразные параметры вариативности и иерархии.

Разрабатывая классификацию семантических типов чилийских, колумбийских, мексиканских, перуанских катойконимов, мы фиксируем случаи межвариантной и внутриязыковой омонимии. Внутриязыковая омонимия, сопряженная с гипо-гиперонимическими отношениями, характерна для всех четырех стран, однако ее проявления всегда уникальны. В Колумбии гипо-гиперонимические отношения свойственны супплетивным вариантным катойконикам. В Мексике 10 названий штатов, имея совпадения с названиями столиц, образуют катойконимы, вступающие в одновременные отношения омонимии и иерархии. Субкультурные компоненты в образовании альтернативных катойконимов связаны с представлениями о рельефе и оценке и мотивируют номинации «своих» и «соседей», или «чужих», образуя этнические реалии (cachaco, costeño, chilango, jarocho, cholo, serrano), переводить которые целесообразно посредством транслитерации. Эти основные выводы могут быть дополнены другими выводами, которые логически вытекают из представленного в статье материала, как минимум, в следующих аспектах.

Политико-административный: Наименьшее из четырех стран количество официальных катойконимов для Чили создает своеобразуню зону катойконимной разреженности, имея на то объективные причины в относительно недавней (2018) административной реформе страны.

Ареальный: Анализ материала позволяет говорить об ареальной дистрибуции суффиксов катойконимов и языковых преференциях социумов. Языковые вкусы и преференции носителей четырех исследованных национальных вариантов испанского языка, таким образом, различны в области катойконимов.

Лингвокогнитивный и имагологический: через супплетивные катойконимы можно проследить представления о «своих» и «чужих». 
Вариантологический: установление межвариантной и внутриязыковой омонимии катойконимов Чили, Колумбии, Мексики, Перу, систематизация их оценочных коннотаций позволяет адекватно интепретировать приращения смысла катойконимов и аксиологические ценности социума.

\section{6. Заключение}

В данной статье нами ставилась цель выявления и систематизации морфологических средств катойконимов стран-основательниц Тихоокеанского Альянса (Чили, Колумбии, Мексики, Перу), установления культурных слоев катойконимов, связанных с административным делением данных стран, выведения параметров вариативности и их лингвокультурологического сопоставления. Это первый в российской и зарубежной романистике опыт исследования катокойнимной репрезентации четырех испаноговорящих стран, входящих в инфраструктуру Тихоокеанского Альянса - важного актора на мировом рынке. Полученные результаты показали, что на формирование катойконимов стран-основательниц Тихоокеанского Альянса (Чили, Колумбии, Мексики, Перу) оказали влияние универсальные тенденции испанского словообразования и одновременно уникальные для каждой страны субкультурные компоненты и коллективные этнические преференции языкового вкуса. Единство звуковой и содержательной стороны национальных катойконимов обусловливает их благозвучие и непротиворечивый смысл, при этом установлена тенденция к локализации морфологических, семантических, аксикологических свойств катойконимов.

Номены статуса крупнейших административных единиц (Región 'Регион' для Чили; Estado 'штат' для Мексики), зафиксированные в их официальных названиях, в образовании катойконимов не участвуют. В случаях топонимов-калек возможная омонимия катойонимов снимается за счет варьирования суффиксального форманта. Техника образования супплетивных катойконимов всегда национально окрашена, подвержена социолингвистической реконструкции и интерпретации, характеризуется уникальностью мотивировки и тенденцией к локализации, что позволяет отнести их к разряду реалий, а катойконимные системы каждой страны - к ономастическим доминантам социума.

Социоисторические факты, географическая среда, восприятие психического склада наций и этнических групп мотивируют экспрессивные обозначения «своих» и «чужих», однако применительно к каждой из рассмотренной стран эти единицы всегда оказываются национально окрашенными и специфичными. Основная тенденция образования супплетивных катойконимов макротопонимов Чили, Колумбии, Мексики, Перу - понятия рельефа, оценка этнического происхождения или ментальности. Катойконимы Чили, Колумбии, Мексики, Перу обнаруживают отношения внутриязыковой, межвариантной омонимии и гипо-гиперонимические отношения. 
Таким образом, катойконимные системы макротопонимов Чили, Колумбии, Мексики, Перу предстают как многомерные национально-специфичные и одновременно принадлежащие единому функциональному испаноязычному континууму сущности. Катойконимы выступают как реалии и генераторы новых смыслов и аллюзий, а их успешное декодирование повышает лингвокультурологическую компетенцию изучающих испанский язык и гармонизирует межкультурный диалог с носителями чилийского, колумбийского, мексиканского, перуанского национальных вариантов испанского языка в качестве деловых партнеров. При переводе супплетивных катойконимов как этнических и региональных реалий предпочтительна транслитерация.

Выведенные параметры морфологического и семантического варьирования чилийских, колумбийских, мексиканских, перуанских катойконимов показывает множественность национальных норм полинационального и поликультурного испанского языка, а своеобразие преференций образует ономастические доминанты социума как устойчивые модели именования географических объектов и производных от них катойконимов. Методология полипарадигмального анализа катойконимных номинаций Чили, Колумбии, Мексики и Перу может быть экстраполирована на другие национальные варианты испанского языка и позволяет прийти к глобальным выводам о развитии испанского языка как знаковой и коммуникативной систем, в том числе в формате lingua franca, что относится к перспективам исследований в будущем.

\section{Финансирование}

Исследование выполнено при поддержке Российского фонда фундаментальных исследований (РФФИ) (проект № 19-012-00316).

(C) Olga Chesnokova and Marija Radović, 2020

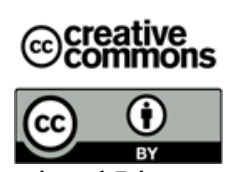

This work is licensed under a Creative Commons Attribution 4.0 International License https://creativecommons.org/licenses/by/4.0/

\section{СПИСОК ЛИТЕРАТУРЫ / REFERENCES}

Ахметова М. Катойконимы как объект метаязыковой рефлексии: орфографический аспект // Антропологический форум. 2019. № 40. С. 115-146. [Akhmetova, M. 2019. Katoikonimy kak ob"ekt metayazykovoi refleksii: orfograficheskii aspekt (Demonyms as the Object of Metalinguistic Reflection: Orphographical Aspect), Antropologicheskii forum. 115-146. (In Russ.)].

Дитрих В. Влияние языков американских индейцев на романские языки (II): «общие языки»: ацтекский, кечуа и тупи. Субстрат, адстрат или интерстрат? (пер. с немецкого В.3. Демьянкова) // Вопросы языкознания. 2002. № 2. C. 64-85. [Ditrikh, V. 2002. Vliyanie yazykov amerikanskikh indeitsev na romanskie yazyki (II): «obshchie 
yazykI»: atstekskii, kechua i tupi. Substrat, adstrat ili interstrat? (per. s nemetskogo V.Z. Dem'yankova) (The influence of American indigenous languages on Romance languages (II) "common languages": Aztec, Quechua and Tupi. Substrate, adstrate or interstrate? (translated from German by Dem'yankova, V.Z.), Voprosy yazykoznaniya. 2, 64-85. (In Russ.)].

Журавлева Н.Ю. Функционирование катойконимов и этнонимов в мексиканском культурном пространстве // Вестник РУДН. Серия: Теория языка. Семиотика. Семантика. 2013. № 4. C. 142-153. [Zhuravleva, N.Yu. 2013. The Functioning of Demonyms and Ethnonyms in Mexican Cultural Space. RUDN University Journal, series "Theory of Language. Semiotics. Semantics" 4. 142-153 (In Russ.)].

Радович M. Los topónimos y gentilicios de Chile у Colombia: su etimología y morfología // Колумбия и Чили: наука, мышление и коммуникация: сборник материалов I Международного междисциплинарного семинара. Москва: ИД «КДУ», «Университетская книга», 2016. С. 54-61. [Radovich, М. 2016. Los topónimos y gentilicios de Chile y Colombia: su etimología y morfología (The Toponyms and Demonyms of Chile and Colombia: Etimology and Morphology), Kolumbiya $i$ Chili: nauka, myshlenie $i$ kommunikatsiya: Sbornik materialov I Mezhdunarodnogo mezhdistsiplinarnogo seminara. 54-61. (In Spanish)].

Степанов Г.В. 1976. Типология языковых состояний и ситуаций в странах романской речи. Москва. [Tipologiya yazykovykh sostoyanii i situatsii v stranakh romanskoi rechi (The Typology of the Linguistic Conditions and Situations in the Romance-speaking Countries). Moscow. (In Russ.)].

Чеснокова О.С. Этнические и региональные реалии Колумбии // Вестник МГОУ. Серия «Лингвистика». 2013. № 4. С. 77-84. [Chesnokova, O.S. 2013. Ehtnicheskie i regional'nye realii Kolumbii (Ethnic and Regional Characteristics of Colombia). Moscow Region State University Journal 4. 77-84. (In Russ.)].

Чеснокова О.С. Испанский язык Мексики: языковая картина мира. М.: ЛЕНАНД, 2020. [Chesnokova, O.S. 2020. Ispanskii yazyk Meksiki: yazykovaya kartina mira (Mexican Spanish: the Linguistic World View). Moscow: LENAND. (In Russ.)].

Ampuero, Roberto. 2012. El último tango de Salvador Allende. Santiago: Sudamericana.

Benites, Alfredo \& Nathalie Lorrain. 2017. Coopérer avec les Chiliens, les Colombiens, les Mexicains et les Péruviens: L'Alliance du Pacifique. Paris, AFNOR Editions.

Bernal, Julio, Alejandro Munévar \& Catalina Barajas. 2014. Actitudes lingüísticas en Colombia. Actitudes lingüisticas de los hispanohablantes hacia el idioma español y sus variantes. Chiquito, Ana Beatriz y Quesada Pacheco, Miguel Ángel (eds.) 5, 180-245. Bergen Language and Linguistic Studies (BeLLS). URL: http://dx.doi.org/10.15845/ bells.v5i0.680 (accessed: 12 May 2020).

Bilá, Magdaléna \& Svetlana Ivanova. 2020. Language, culture and ideology in discursive practices. Russian Journal of Linguistics 24 (2). 219-252. URL: https://doi.org/ 10.22363/2687-0088-2020-24-2-219-252

Bilá, Magdaléna, Alena Kačmárová \& Ingrida Vaňková. 2020. The encounter of two cultural identities: The case of social deixis. Russian Journal of Linguistics 24 (2). 344-365. DOI: 10.22363/2687-0088-2020-24-2-344-365

Chávez Fajardo, Soledad \& Raïssa Kordic Riquelme. 2019. Acerca del gentilicio: historiografía, remoquetes y estandarización. Literatura y lingüística 39. 275-300. URL: http://dx.doi.org/10.29344/0717621x.39.2014 (accessed: 27 May 2020).

Estrada Flórez, Rosa Elvira \& José Manuel Pérez Adárraga. 2020. Las creencias y percepciones de los habitantes de Valledupar sobre el término vallenato como gentilicio. Lingüística y Literatura 41 (78). 110-139. URL: https://doi.org/10.17533/udea.lyl.n78a05 (accessed: 3 June 2020). 
Ospina, Andrés. 2016. Bogotálogo (Tercera edición) II. Usos, desusos y abusos del español hablado en Bogotá. Bogotá: Instituto Distrital de Patrimonio Cultural.

Ilyin, Dmitry \& Elena Sidorova. 2015. Derivational Potential of Toponymical System: Formation and Functioning of Katoikonyms. Science Journal of Volgograd State University. Linguistics 3 (27). 7-14. URL: http://dx.doi.org/10.15688/jvolsu2.2015.3.1. (accessed: 2 May 2020).

García Padrón, Dolores \& Marcial Morera Pérez. 2015. Gentilicios y lexicografía. Onomázein 31. 81-98. https://www.redalyc.org/articulo.oa?id=1345/134544049007 (accessed: 12 March 2020).

Kordic Riquelme, Raïssa \& Soledad Chávez Fajardo. 2017. Qué se entiende por gentilicio. Aproximaciones onomasiológicas, sintácticas y morfológicas. Prolegómenos. Boletín de Filología 52 (1). 213-244.

Larina, Tatiana. 2015. Culture-specific communicative styles as a framework for interpreting linguistic and cultural idiosyncrasies. International Review of Pragmatics 7 (5). Special issue: Communicative Styles and Genres. 195-215.

Larina, Tatiana, Vladimir Ozyumenko \& Svetlana Kurteš. 2017. I-identity vs We-identity in language and liscourse: Anglo-Slavonic perspectives. Lodz Papers in Pragmatics 13 (1). $109-128$.

Loester, Barbara. 2017. "A Significant Part of an Insignificant Identity": Tradition, globalisation and the re-articulation of North-East Scots. Russian Journal of Linguistics 21 (2). 335-347.

Luna Cabrera \& Julio Eduardo. 2005. Su Majestad el Refrán. Manizales.

Malyuga, Elena, Alex Krouglov \& Barry Tomalin. 2018. Linguo-cultural competence as a cornerstone of translators' performance in the domain of intercultural business communication. XLinguae 11 (2). 566-582. URL: http://xlinguae.eu/2018_11_02_46.html (accessed: 18 March 2020).

Martinić, Mateo. 2005. De la Trapananda al Aysén: una mirada reflexiva sobre el acontecer de la Región de Aysén desde la Prehistoria hasta nuestros días. Santiago: Pehuén Editores.

Moreno de Alba, José Guadalupe. 2001. El español en América. Tercera edición, corregida y aumentada. México: Fondo de Cultura Económica.

Morera, Marcial. 2015. El gentilicio en español: aspectos teóricos y prácticos. Madrid: Arco/Libros, S.L.

Mugford, Gerrard. 2020. Mexican politeness: an empirical study on the reasons underlying/motivating practices to construct local interpersonal relationships. Russian Journal of Linguistics 24 (1). 31-55. URL: https://doi.org/10.22363/2687-0088-2020-241-31-55 (accessed: 18 June 2020).

Pinto, Carlos Felipe \& Camilla Guimarães Santero Pontes. 2020. La Variación Socioespacial del español actual: el español como lengua franca y la enseñanza del español como lengua extranjera. Intertexto 13 (1). 172-213.

Ripoll, Alejandra (ed.) 2018. La Alianza del Pacífico ¿atrapada en el péndulo del regionalismo y del interregionalismo? Bogotá: Opciones Gráficas Editores.

Tent, Jan. 2018. What's in a Demonym? A Note on a New and Uplifting Ethnonym. Names. A Journal of Onomastics 2 (66). 103-105. URL: https://doi.org/10.1080/00277738.2017. 1415543 (accessed: 11 March 2020).

Vargas López, Sergio Iván. 2018. Vallenato y discurso, una aproximación a partir de sus canciones. Corporación Universitaria Minuto de Dios. Bogotá, D.C. URL: https://repository.uniminuto.edu/bitstream/handle/10656/6407/T.HUM_VargasLopezSer gioIvan_2018.pdf (accessed: 5 April 2020).

Velasco Valdés, Miguel. 1998. Refranero popular mexicano (11 edición). México: CostaAmic. 


\section{Словари / Dictionaries}

Словарь персоналий Тихоокеанского Альянса = Diccionario de personalidades de la Alianza del Расі́fico / под ред. О.С. Чесноковой. Москва: РУДН, 2020. [Chesnokova, O.S. (ed). 2020. The Dictionary of Illustrious Personalities of the Pacific Alliance. Moscow: RUDN. (In Russ.)].

Словари и энциклопедии на Академике. URL: www.dic.academic.ru (accessed: 5 April 2020).

Поспелов Е.М. 2007. Иллюстрированный атлас мира. География мира: новейший топонимический словарь: ок. 8000 единиц / Е.М. Поспелов. М.: Русские словари: Астрель: АСТ: Хранитель. [Pospelov, Е.М. 2007. Illyustrirovannyi atlas mira. Geografiya mira: noveishii toponimicheskii slovar': ok. 8000 edinits (The Illustrated World Atlas. World Geography: the Newest Toponymic Dictionary: around 8,000 units). Moscow: Russkie slovari: Astrel': AST: Khranitel', (In Russ.)].

Breve diccionario de colombianismos. $3^{\mathrm{a}}$ ed. (2009) Bogotá: Academia Colombiana de la Lengua.

Luna Cabrera, Julio Eduardo. 2002. Diccionario de aztequismos. México: Colofón.

Diccionario de americanismos. 2010. Lima: Santillana.

Diccionario de gentilicios de Colombia. 2008. Bogotá: Imprenta Nacional de Colombia, $2008.176 \mathrm{p}$.

Diccionario educativo del estudiante. 2009. Bogotá: Larousse.

Diccionario Enciclopédico Vox 1. 2009. Larousse Editorial, S.L., 2009. URL: https://es.thefreedictionary.com/gentilicio (дата обращения: 3 июня 2020)

Montoya, Ramiro. 2006. Diccionario comentado del español actual en Colombia. Bogotá: Ed. Párrafo.

Richard, Renaud. 1997. Diccionario de hispanoamericanismos no recogidos por la Real Academia. $2^{a}$ ed. Madrid: Cátedra.

Santamaría, Francisco. 2000. Diccionario de mejicanismos. 6a. ed. México: Porrúa.

Diccionario de la Real Academia Española (DRAE). URL: www.dle.rae.es (accessed: 15 April 2020).

Diccionario del Español de México (DEM). URL: http://dem.colmex.mx; El Colegio de México, A.C.

\section{Электронные ресурсы / Internet resources}

Антиокия, Википедия. URL: https://es.wikipedia.org/wiki/Antioquia (accessed: 20 May 2020).

Территориальная организация Чили, Википедия. URL: https://es.wikipedia.org/wiki/ Organizaci\%C3\%B3n_territorial_de_Chile (accessed: 17 May 2020).

"El Magallánico" cumple dōs años". ÜRL: https://elmagallanico.com/2019/08/el-magallanicocumple-dos-anos-informando-a-la-region (accessed: 29 May 2020).

Magallanes: curiosidades de un pueblo único. URL: https://www.cocacoladechile.cl/historias/ gente-magallanicos-curiosidades-de-un-pueblo-unico (accessed: 26 May 2020).

Агуаскальентес, Википедия. URL: https://es.wikipedia.org/wiki/Aguascalientes (accessed: 1 June 2020).

Equipo. URL: https://infoling.org/?lang=es\&p=equipo (accessed 28 May 2020).

Jergozo. URL: https://jergozo.com/significado/chilango (accessed 28 May 2020).

Chimpum Callao. URL: http://www.chimpum-callao.com/historia.html (accessed: 25 May 2020).

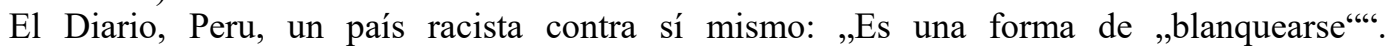
URL: https://www.eldiario.es/desalambre/Peru-pais-racista-mismo_0_254775486.html (accessed: 2 June 2020). 
BBC News, Por qué a muchos peruanos les cuesta reconocerse como cholos. URL: https://www.bbc.com/mundo/noticias-america-latina-37489332 (accessed: 2 June 2020).

\section{Article history:}

Received: 20 August 2020

Revised: 28 November 2020

Accepted: 1 December 2020

\section{История статьи:}

Дата поступления в редакцию: 20 августа 2020

Дата принятия к печати: 1 декабря 2020

\section{Сведения об авторах:}

Ольга Станиславовна ЧЕСНОКОВА - доктор филологических наук, профессор, профессор кафедры иностранных языков филологического факультета Российского университета дружбы народов (РУДН). Член Американского Ономастического Общества. Ее исследовательские интересы охватывают варьирование испанского языка, ономастику, лингвокультурологию, межкультурную коммуникацию, семиотику и перевод художественного текста. Она является автором более 200 публикаций на русском, английском, испанском языках, включая монографии, учебники, главы книг, а также многочисленные статьи.

\section{Контактная информация:}

Российский университет дружбы народов

117198, г. Москва, ул. Миклухо-Маклая, д. 10 А,

e-mail: chesnokova-os@rudn.ru

ORCID ID: 0000-0001-7025-4098

Мария РАДОВИЧ - кандидат филологических наук, ассистент кафедры иностранных языков филологического факультета Российского университета дружбы народов (РУДН).

Исследовательские интересы: топонимика испанского языка, вариативность испанского и португальского языков, лингвокультурология, лексикография, межкультурная коммуникация, переводоведение. Она является автором более 30 публикаций, среди которых одна монография.

\section{Контактная информация:}

Российский университет дружбы народов

117198, Москва, ул. Миклухо-Маклая, д. 10 А

e-mail: radovich-m@pfur.ru

ORCID ID: 0000-0002-8099-0184

\section{Bionotes:}

Olga CHESNOKOVA, Ph.D. (Advanced Doctorate) in Philology, Full-time Professor at the Department of Foreign Languages of the Faculty of Philology of the RUDN University. She is a member of the American Name Society. Her research interests include variations of the Spanish language, onomastics, cultural linguistics, intercultural communication, semiotics and literary translation. She has authored over 200 publications in Russian, 
English and Spanish, including monographs, textbooks, book chapters and numerous journal articles.

\section{Contact information}

Peoples' Friendship University of Russia

10/A Miklukho-Maklaya Street, Moscow, 117198

e-mail: chesnokova-os@rudn.ru

ORCID ID: 0000-0001-7025-4098

Marija RADOVIĆ is a Ph.D., Assistant Lecturer at the Department of Foreign Languages of the Faculty of Philology of the RUDN University. Her research interests include Spanish toponymy, variations of the Spanish and Portuguese languages, cultural linguistics, lexicography, intercultural communication and translation studies.

\section{Contact information}

Peoples' Friendship University of Russia

10/A Miklukho-Maklaya Street, Moscow, 117198

e-mail: radovich-m@pfur.ru

ORCID ID: 0000-0002-8099-0184 